\title{
A Rare Cause of Chronic Pelvic Pain in Young Man: Magnetic Resonance Imaging Findings of Zinner's Syndrome
}

\author{
Genç Erkekte Kronik Pelvik Ağrının Nadir Bir Nedeni: Zinner Sendromunun Manyetik \\ Rezonans Görüntüleme Bulguları
}

\author{
(1) Serdar Aslan \\ Giresun University Faculty of Medicine, Department of Radiology, Giresun, Turkiye
}

\begin{abstract}
Chronic pelvic pain is more uncommon in men than in women, and it is often thought to be due to problems with the urogenital system. The maldevelopment of the urogenital system is a rare condition, and frequently detected incidentally. Zinner's syndrome is a rare urogenital system development anomaly comprising a triad of unilateral renal agenesis, ipsilateral seminal vesicle cyst, and ejaculatory duct obstruction. Patients with this anomaly are often asymptomatic until the second or third decade of life. Some patients present with non-specific symptoms, such as prostatism, frequent micturition, recurrent urinary tract infections, painful ejaculation, and chronic pelvic pain. Here, we present the magnetic resonance imaging findings in a 27-year-old patient who had experienced pelvic pain for two years and was diagnosed with Zinner's syndrome in our clinic. Keywords: Pelvic pain, Magnetic resonance, Zinner's syndrome, Renal agenesis

Öz

Erkeklerde kronik pelvik ağrı kadınlara göre daha nadir olarak görülür, sıklıkla ürogenital sistem kaynaklı olduğu düşünülmektedir. Ürogenital sistemin gelişimsel anomalileri nadirdir ve sıklıkla tesadüfen tespit edilir. Zinner sendromu, tek taraflı böbrek agenezisi, aynı taraflı seminal vezikül kistleri ve ejakülatör kanal tıkanıklığını içeren nadir bir ürogenital sistem gelişme anomalisidir. Bu anomali sıklıkla yaşamın ikinci veya üçüncü dekadına kadar asemptomatiktir. Bazı olgularda prostatizm, sık idrara çıkma ihtiyacı, tekrarlayan idrar yolu enfeksiyonları, ağrılı boşalma ve kronik pelvik ağrı gibi spesifik olmayan semptomlar vardır. Biz burada, iki yıldır pelvik ağrı şikayeti olan ve tarafımızca Zinner sendromu tanısı alan 27 yaşındaki hastada, manyetik rezonans görüntüleme bulgularını sunmayı amaçladık.
\end{abstract}

Keywords: Pelvik ağrı, Manyetik rezonans, Zinner sendromu, Renal agenezi

\section{Introduction}

Congenital malformations of the seminal vesicle are rare, and the majority of them are cystic malformations. Such malformations are generally seen on the right side (1). Seminal vesicle cysts (SVC) may occur in an isolated form, or they may be associated with upper urinary tract anomalies. Absence of the ureteric bud and abnormal development of the mesonephric duct (Wolffian) during embryogenesis leads to ipsilateral renal agenesis and atresia of the ejaculatory duct. This subsequently progresses to cystic dilation of seminal vesicles. This association was first described by Zinner (2) in 1914. Zinner's syndrome comprises a triad of ejaculatory duct obstruction, unilateral renal agenesis and SVC. Two hundred cases of Zinner's syndrome have been reported in the literature. The majority of patients typically remain asymptomatic until the second or third decade of life. Some patients report non-specific symptoms, including prostatism, frequent micturition, recurrent urinary tract infections, painful ejaculation, and chronic pelvic pain. Patients with Zinner's syndrome are often diagnosed incidentally following radiological examinations performed for other reasons. Here, we present magnetic resonance imaging (MRI) findings in a 27-year-old patient who experienced pelvic pain for two years and was diagnosed with Zinner's syndrome in our clinic.

Correspondence: Aslan Serdar MD, Giresun University Faculty of Medicine, Department of Radiology, Giresun, Turkiye E-mail: serdaraslan28@hotmail.com ORCID-ID: orcid.org/0000-0003-2950-8767

Received: 23.04.2019 Accepted: 15.05.2019

Cite this article as: Aslan S. A Rare Cause of Chronic Pelvic Pain in Young Man: Magnetic Resonance Imaging Findings of Zinner's Syndrome. J Urol Surg 2019;6(4):331-334.

๑Copyright 2019 by the Association of Urological Surgery / Journal of Urological Surgery published by Galenos Publishing House. 


\section{Case Report}

A 27-year-old male patient was referred to our clinic by an urologist after having experienced recurrent episodes of intermittent pelvic pain over the course of two years. He did not report any lower urinary tract symptoms, gross hematuria, or trauma. He had previously experienced the same problem, which was resolved following administration of non-steroidal anti-inflammatory medications. He was not married and he had no children.

To determine the etiology of his pelvic pain, abdominopelvic ultrasonography (US) was performed which revealed absence of the left kidney, compensatory hypertrophy of the right kidney, and presence of enlarged tubular structures in the retrovesical region and in the cephalic direction to the prostate. The patient was then subjected to abdominopelvic MRI for further evaluation. The abdominopelvic MRI identified round cystic masses $(60 \times 47 \times 45 \mathrm{~mm})$ in the left seminal vesicle, with the contents of the masses demonstrating high signal intensity on the T1-weighted images (T1WI) and low signal intensity on the T2-WI (Figure 1). Enlargement of the left ejaculatory duct was also observed (Figure 2). Further, there was no lymphadenopathy or iliac or pelvic effusion. There was no evidence of a left ectopic kidney, and the absence of the left kidney was confirmed on the MRI images (Figure 3). Scrotal US was performed to rule out any possible accompanying testicular pathology. It revealed that both testes were within the normal limits. Based on all these findings, the patient was diagnosed with Zinner's syndrome. Due to the known influence of Zinner's syndrome on an individual's fertility status, the patient was asked to undergo a semen analysis, the results of which were normal. The patient was referred for surgery because of his chronic pelvic

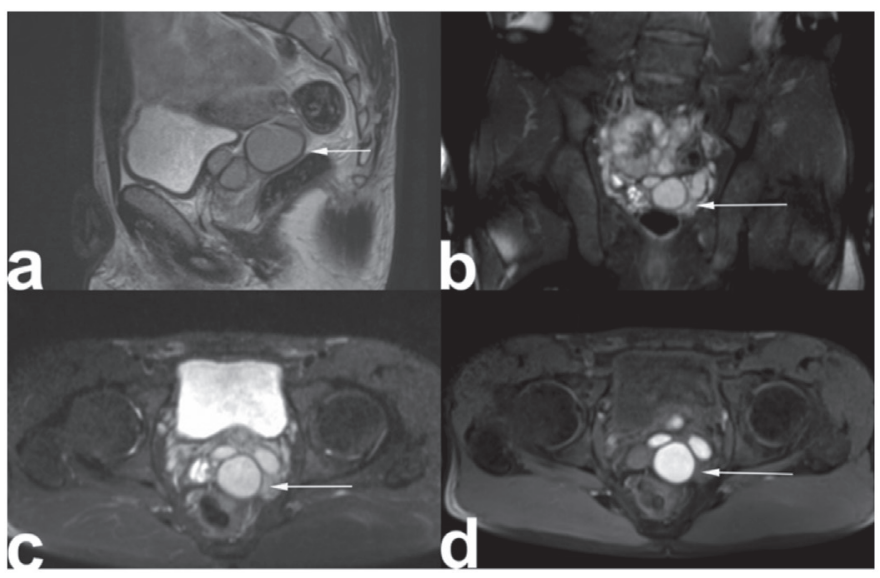

Figure 1. a) Sagittal T2 weighted image (WI), b) coronal and, c) axial fatsaturated T2WI magnetic resonance imaging images shows dilated, multiple cystic intercommunicating left seminal vesicle cyst, hypointense according to urine. d) Axial T1WI shows hyperintense multiloculated left seminal vesicle cyst, reflecting probably increased concentration of proteinaceous fluid or haemorrhage (arrows) pain. Transurethral unroofing of the SVCs was performed for treatment and intraoperative findings confirmed our diagnosis. We kept him in a follow-up program after surgery; at the 6-month follow-up, he remained asymptomatic. The patient did not describe retrograde ejaculation during the follow-up period and the results of semen analysis performed 6 months after surgery were also normal. Written informed consent was obtained from the patient.

\section{Discussion}

Zinner's syndrome is a rare congenital malformation of the seminal vesicles, ejaculatory duct and the ipsilateral upper urinary tract (1). It is considered to be the male counterpart of Mayer-rokitansky-kuster-hauser syndrome seen in females (3). The relationship between upper urinary tract abnormalities and seminal vesicle malformations results from the common origin of the ureteric bud and the seminal vesicles, which stem from the mesonephric (Wolffian) duct (4). An incident occurring during the first trimester, especially prior to the $7^{\text {th }}$ week of gestation, can cause the maldevelopment of the distal part of the Wolffian duct, thereby resulting in atresia in both the ejaculatory duct and the ureteric bud (5). If the ureteric bud develops in a more cephalic position in relation to the mesonephric duct blastema, it will cause delayed absorption of the caudal mesonephric duct leading to the distal ureteric bud emptying into mesonephric derivatives $(1,6)$. Thus, secretions will accumulate in the seminal

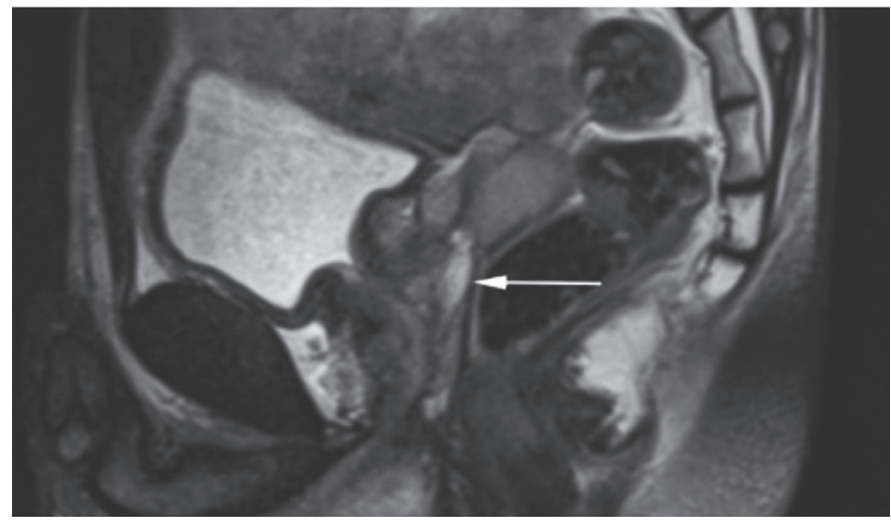

Figure 2. Sagittal T2 weighted image magnetic resonance imaging images shows enlargement of ejaculatory duct (arrow)

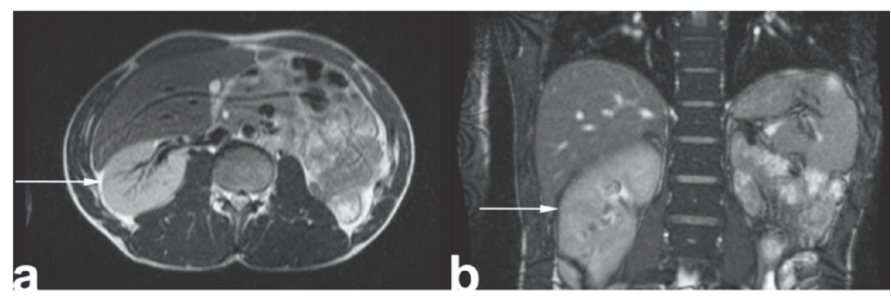

Figure 3. a) Axial and, b) coronal T2 weighted image magnetic resonance imaging images shows compensatory right kidney and left kidney fossa empty (arrows) 
vesicle due to these drainage problems. Generally speaking, renal agenesis is unilateral and ipsilateral. Only three cases of contralateral renal agenesis coexisting with SVC have been reported in the literature (7).

The majority of patients typically remain asymptomatic until the second or third decade of life, which corresponds to the period characterized by the highest level of reproductive activity. Prior to this period, such malformations tend to be detected only incidentally during imaging procedures performed for other reasons. Secretions accumulate due to ejaculatory duct obstruction and insufficient drainage. As a result, seminal vesicles enlarge progressively and symptoms appear (4). Cysts larger than $6 \mathrm{~cm}$ may cause pressure on the bladder or prostate, and they may also cause obstructive symptoms. The symptomatology described in the previous literature is nonspecific and varied, including prostatism, dysuria, frequent urination, recurrent urinary tract infections, painful ejaculation, and chronic pelvic pain (8). In addition, patients may present with infertility. For this reason, the patient's fertility status should always be investigated following a diagnosis of Zinner's syndrome. Due to the ejaculatory duct obstruction, a low ejaculation volume, which is typically less than $1 \mathrm{~mL}$, can be associated with azoospermia. In our case, although the cyst was larger than $6 \mathrm{~cm}$, there were no obstructive symptoms and the patient instead presented with chronic pelvic pain. The patient's semen analysis was normal.

The method of imaging is of great importance in the diagnosis. US is generally the preferred initial imaging method, and it can provide very useful information for diagnosis. On our patient's abdominopelvic US, the ipsilateral kidney was found to be absent, compensatory hypertrophy was noted in the contralateral kidney, and the obstructed ejaculatory ducts were seen as anechoic structures in the pelvis, although it should be noted that hemorrhage can produce low-level internal echoes (9). Computed tomography may actually perform better as an imaging method than US in this regard, since it is capable of showing the absence of the ipsilateral kidney and the presence of a SVC, although its findings may prove insufficient to confirm the diagnosis. MRI is the preferred method for gathering highresolution tissue contrast data for the definitive identification of the anatomy of the male genital tract, the examination of the seminal vesicles, and the evaluation of any mesonephric duct anomalies, as well as for distinguishing SVCs from other cystic pelvic masses. On MRI, SVCs are in a characteristic periprostatic and paramedian location, with hyperintensity on $\mathrm{T} 2 \mathrm{WI}$ and variable intensity on $\mathrm{T} 1 \mathrm{WI}$, depending on the amount of protein or blood content, no contrast enhancement after gadolinium and no restriction on diffusion-weighted imaging (10). MRI may also be helpful in surgical planning for the excision of SVCs when surgical treatment is appropriate. In our case, similar to that in the literature, US showed that the left kidney was absent, and there was compensatory hypertrophy in the right kidney. In addition, dilated cystic structures were observed in the periprostatic area in the retrovesical region. On MRI, cystic dilatation of the left seminal vesicle showed high signal intensity on T1WI and low signal intensity on T2WI. Enlargement of the left ejaculatory duct was also observed.

The differential diagnosis of SVC includes vesical diverticula, prostatic utricle cysts, ejaculatory duct cysts, ectopic hydronephrotic kidney, ectopic ureteroceles, and abscess. The main differentiation is usually based upon the location: median, para-median, or lateral. In addition, accompanying developmental abnormalities (renal agenesis or anomalies of the external genitalia) may help the differential diagnosis (11). Vesical diverticula are para-median, ejaculatory duct cysts are midline in location. Diverticulosis of ampulla of the vas deferens and ectopic ureterocele are more laterally located.

Treatment should be clinically oriented and SVC should be followed up in asymptomatic and minimally symptomatic cases (12). Conservative treatment with antibiotics, transurethral needle aspiration of the cyst or transurethral aspiration combined with substance instillation (alcohol and minocycline) is suitable for patients with mild symptoms. Invasive treatment should be restricted to symptomatic cases or to patients who have failed conservative measures. The minimally invasive approach with laparoscopic surgery and, most recently, the robot-assisted approach have gained substantial acceptance and are the preferred methods in most cases. In our case, transurethral cyst unroofing, a minimally invasive method for treatment, was performed and the patient remained asymptomatic during the 6 months of follow-up.

Congenital malformations of the urogenital system are often not considered by clinicians when patients present with nonspecific symptoms. Imaging methods alone have the ability to provide a precise diagnosis. Familiarity with the imaging findings of this anomaly and keeping in mind such findings are essential for a prompt diagnosis. MRI is proven best for identification of anatomy of the male genital system. In appropriate cases, minimally invasive methods (transurethral cyst unroofing or transurethral aspiration combined with substance instillation) may be used for treatment.

\section{Ethics}

Informed Consent: Written informed consent was obtained from the patient.

Peer-review: Externally peer-reviewed.

Financial Disclosure: The authors declared that this study received no financial support. 


\section{References}

1. Pereira $B J$, Sousa $L$, Azinhais $P$, Conceição $P$, Borges $R$, Leão $R$, Brandão $A$, Temido $P$, Retroz E, Sobral F. Zinner's syndrome: an up-to-date review of the literature based on a clinical case. Andrologia 2009;41:322-330.

2. Zinner A . Ein fall von intravesikaler samenblasenzyste. Weien Med Wschr 1914;64:604-610.

3. Gianna P, Giuseppe PG. Mayer-Rokitansky-Kuster-Hauser syndrome and the Zinner syndrome, female and male malformation of reproductive system: are two separate entities? J Chinese Clin Med 2007;2:11.

4. Kao CC, Wu CJ, Sun GH, Yu DS, Chen HI, Chang SY, Ma CP, Cha TL. Congenital seminal vesicle cyst associated with ipsilateral renal agenesis mimicking bladder outlet obstruction: a case report and review of the literature. Kaohsiung J Med Sci 2010;26:30-34.

5. Livingston L, Larson CR. Seminal vesicle cyst with ipsilateral renal agenesis. AJR Am J Roentgenol 2000;175:177-180.

6. Arora SS, Breiman RS, Webb EM, Westphalen AC, Yeh BM, Coakley FV. CT and MRI of congenital anomalies of the seminal vesicles. Am J Roentgenol 2007;189:130-135.
7. Kosan M, Tul M, Inal G, Ugurlu O, Adsan O. A large seminal vesicle cyst with contralateral renal agenesis. Int Urol Nephrol 2006;38:591-592.

8. Kenney PJ, Leeson MD. Congenital anomalies of the seminal vesicles: spectrum of computed tomographic findings. Radiology 1983;149:247251.

9. Trigaux JP, Van Beers B, Delchambre F. Male genital tract malformations associated with ipsilateral renal agenesis: sonographic findings. J Clin Ultrasound 1991;19:3e10.

10. Cihan A, Cimen S, Secil M, Kefi A, Aslan G. Congenital seminal vesicle cyst accompanying ipsilateral renal agenesis and rudimentary ureter. Int Urol Nephrol 2006;38:133-135.

11. Sundar R, Sundar G. Zinner syndrome: an uncommon cause of painful ejaculation. BMJ Case Rep 2015:2015.

12. King $B F$, Hattery RR, Lieber MM, Berquist $T H$, Williamson B Jr, Hartman GW. Congenital cystic disease of the seminal vesicle. Radiology 1991;178:207211. 